\title{
The Impact of Using Social Networking Sites on Efficiency in Work and Inter-Personal Relations \\ Simran $^{*}$
}

Department of Commerce, School of Open Learning, University of Delhi, India

DOI: $10.36347 /$ sjahss.2021.v09i03.001

| Received: 16.02.2021 | Accepted: 28.02.2021 | Published: 10.03.2021

*Corresponding author: Simran

Abstract

Original Research Article

The aim of this study is to explore the impact Social Networking Sites have on efficiency in work and interpersonal relations of people in offices and other work places. For this purpose a survey was conducted in which a questionnaire by the medium, google forms was circulated. It consists of 2 sections, first one intending to understand the demography of cases and second one intended to get information for being able to fulfil purpose of our study. The data was analysed quantitatively using SPSS program version 19. The study concluded that Social Networking Sites are a great resource for individuals and organisations if used in a prudent way. At the same time can be problematic, if not used rationally.

Keywords: Social Networking Sites, Inter-Personal Relations.

Copyright $($ ) 2021 The Author(s): This is an open-access article distributed under the terms of the Creative Commons Attribution 4.0 International License (CC BY-NC 4.0) which permits unrestricted use, distribution, and reproduction in any medium for non-commercial use provided the original author and source are credited.

\section{INTRODUCTION}

Social Networking Sites (SNSs) provides an online platform which enables it's users to form a social network among selected people sharing similar professional and personal interests, for the purpose of interaction and communication in a free and open manner.

These sites are accessed through an electronic device which requires internet connection. These sites allow users to share information, pictures, videos, locations, and other such data.

Social Networking Sites (SNSs) are becoming an indispensable part of today's growing world, where various functions such as marketing, recruitment, communication of important information are being done using SNS by a lot of organisations across the globe. Thus it becomes necessary to understand the implications of it, opinion of people using it, extent to which it has penetrated and altered people's lives.

There is no doubt that use of SNS have revolutionised the way tasks are carried out today in organisations as well as how well people use it daily to make their communications convenient and more affective. Since there are no free lunches in the world it is important to it examine carefully, that seems highly productive for mankind, and take measures to keep it a useful resource.

It is significant to study the impact of SNSs since it has become an empirical part of the modern world, and affects human lives in distinct ways.

Limitation of the research-

1) Explore the extent to which teenagers are affected by SNSs.

2) Study the pattern of teenager's interaction with SNSs.

\section{LITERATURE REVIEW}

Uses and gratifications theory (U\&G)-It is a very common theory which explains the reasons which influence people to engage in usage of SNS. This theory was proposed by Elihu Katz, Jay Blumler and Michael Gurevitch in 1973. The purpose was to study what motivates people for engaging with the media that they do to satisfy their needs.

Katz, Blumler \& Gurevitch [1]. U\&G is a psychological theory that concludes individuals are actively engaged in seeking medium that are believed to be appropriate for satisfying particular needs [1, 2]. $U \& G$ points out that consumer have their own choices as to which media and what kind of medium they wish 
to consume for the purpose of receiving greater satisfaction in accordance with their needs [3].

\section{Interpersonal relations}

The study focus on how usage of social networking sites(SNS) i.e. online media affect their relations with people present with them in physical space.

Chotpitayasunondh and Douglas [4] coined and defined a new term known as "phubbing" which means "the act of snubbing someone in a social setting by concentrating on one's phone instead of talking to the person directly"(p.10). This behaviour was observed to be growing in common public places and people stated viewing is as normal instead of rude. This behaviour was found more prominently in people addicted to smart phones.

\section{Underutilised area}

Organisations across the world haven't fully tapped the benefits that accompany social networking technologies in work place. A lot of organisations are moving towards it. There is still a lot of potential in this area which is undiscovered. People are not able to reap benefits because of fear, resistance and risks [5].

Technological mechanics have created a novel, revolutionised environment specially the internet in 'all spheres of personal, social and professional human life. Right from the mere ways of interaction to the running of human system, we are utilising the conveniences provided by the existence of internet [6].

Social Networking Sites (SNS) have changed the way people interact and stay connected with one another in the society, 'even though they may be sitting home alone at their computer or with their mobile phones. Participants connect with other people they know through school, or an organisation, they also meet complete strangers from all over the world' [7].

In relation to ongoing research about high pace adoption of SNSs Nielsen Wire, 2010 raised an empirical concern about the impact of its usage. However, it is up to individuals about the way of their usage either for accessing information, debating, socialising or entertainment [8]. Thus different ways of usage may have distinct implications on individuals, organisations and society as a whole [9].
There are a lot of other researches that conclude how social media is effective and at the same time dangerous based on the way and for the purpose people use it.

\section{Objectives of the study}

1. To study the demography of the cases (Gender, Education Qualification, Age).

2. To study association between most preferred SNS with purpose of use.

3. To understand the relation in opinion on SNS affecting inter-personal relationship among colleagues and disturbing regular work in office.

4. To find out link in picking calls and allowing picking calls during work.

5. To understand relation in change in attitude and time spent on SNS.

6. To find relation in monthly mobile bill and kind of connection.

\section{Data and Data sources, Methodology}

Data- Quantitative data has been collected in the survey, consisting of both open-ended and closeended information.

\section{Data Source}

Primary data is obtained from 100 respondents from different age groups belonging to Delhi NCR and some regions of Bangalore and Hyderabad. The purpose is to understand their views on usage of SNS affecting work efficiency and inter personal relations.

A structured questionnaire was prepared on a Google form with 22 variables and was floated in various groups and personally on Whatsapp social networking application.

\section{METHODOLOGY}

Random purposive sampling was used where in data is collected through Google form, floated on online social networking application called Whatsapp, through mail and SMS. Empirical research method has been followed while conducting this study. It tries to study the extent to which Social media Sites have impacted people, their mindsets, attitudes, opinions and routine.

\section{Data Analysis and Interpretation}

Objective 1:- To study the demography of the cases (Gender, Education Qualification, Age).

\begin{tabular}{|l|l|l|l|l|l|}
\hline \multicolumn{2}{|l|}{ Gender } & Frequency & Percent & $\begin{array}{l}\text { Valid } \\
\text { Percent }\end{array}$ & $\begin{array}{l}\text { Cumulative } \\
\text { Percent }\end{array}$ \\
\hline \multirow{3}{*}{ Valid } & Male & 43 & 43.0 & 43.0 & 43.0 \\
\cline { 2 - 6 } & Female & 56 & 56.0 & 56.0 & 99.0 \\
\cline { 2 - 6 } & LGBTQ & 1 & 1.0 & 1.0 & 100.0 \\
\cline { 2 - 6 } & Total & 100 & 100.0 & 100.0 & \\
\hline
\end{tabular}


The data collected have most responses from Female that is $56 \%$ followed by male that is $43 \%$ and just $1 \%$ responses came from LGBTQ category.

\begin{tabular}{|c|c|c|c|c|c|}
\hline \multicolumn{6}{|c|}{ Educational qualification of the respondent- } \\
\hline & & Frequency & Percent & Valid Percent & Cumulative Percent \\
\hline \multirow[t]{4}{*}{ Valid } & Graduate & 59 & 59.0 & 59.0 & 59.0 \\
\hline & Post graduate & 40 & 40.0 & 40.0 & 99.0 \\
\hline & M.Phil/PhD & 1 & 1.0 & 1.0 & 100.0 \\
\hline & Total & 100 & 100.0 & 100.0 & \\
\hline
\end{tabular}

The data collected have most responses from Graduates that is $59 \%$ followed by Post graduates that is $40 \%$ and just $1 \%$ responses came from $\mathrm{M}$. Phil/PhD students.

\begin{tabular}{|l|l|l|l|l|l|}
\hline Descriptive Statistics & N & Minimum & Maximum & Mean & Std. Deviation \\
\hline Age- & 100 & 18 & 55 & 27.20 & 6.554 \\
\hline Valid N (list wise) & 100 & & & & \\
\hline
\end{tabular}

- The data collected have most responses from age group ranging from 18-55years.

- Average age of the respondents is 27 years which indicates on an average data is collected from adults, in the starting of their career.

\begin{tabular}{|c|c|c|c|c|c|c|}
\hline \multicolumn{7}{|c|}{$\begin{array}{l}\text { Which SNS do you prefer to use * purpose of using SNS Cross tabulation } \\
\text { Count }\end{array}$} \\
\hline & & \multicolumn{4}{|c|}{ purpose of using SNS } & \multirow[t]{2}{*}{ Total } \\
\hline & & $\begin{array}{l}\text { To meet } \\
\text { new people }\end{array}$ & $\begin{array}{l}\text { To stay in touch } \\
\text { with friends }\end{array}$ & For fun & $\begin{array}{l}\text { To stay in touch } \\
\text { with family }\end{array}$ & \\
\hline \multirow{4}{*}{$\begin{array}{l}\text { Which SNS do you } \\
\text { prefer to use }\end{array}$} & Whatsapp & 2 & 53 & 8 & 8 & 71 \\
\hline & Facebook & 1 & 2 & 3 & 1 & 7 \\
\hline & Instagram & 0 & 4 & 3 & 0 & 7 \\
\hline & Other & 0 & 8 & 6 & 1 & 15 \\
\hline \multicolumn{2}{|l|}{ Total } & 3 & 67 & 20 & 10 & 100 \\
\hline
\end{tabular}

\section{Inference}

- People prefer whatsapp the most among other Social Networking Sites i.e. out of 100, 71 respondents prefer Whatsapp, followed by other sites.

- Out of the 71 people who prefer Whatsapp, most of them (53) use it for the purpose of staying in touch with friends.

- Out of the 7 people who prefer Facebook, most of them (3) use it for fun.
Objective 2:- To study association between most preferred SNS with purpose of use.

\begin{tabular}{|l|l|l|l|}
\hline Chi-Square Tests & Value & df & Asymp. Sig. (2-sided) \\
\hline & $16.688^{\text {a }}$ & 9 & .054 \\
\hline Pearson Chi-Square & 15.909 & 9 & .069 \\
\hline Likelihood Ratio & 1.199 & 1 & .273 \\
\hline Linear-by-Linear Association & 98 & & \\
\hline N of Valid Cases & \multicolumn{5}{|l}{} \\
\hline a. 12 cells (75.0\%) have expected count less than 5. The minimum expected count is .21. \\
\hline
\end{tabular}




\section{Inference}

\begin{tabular}{|l|l|}
\hline Hypothesis & Ho: there is no significant association between the variables. \\
\hline Interpretation & $\begin{array}{l}\text { Since, the computed P-value }=0.054>0.05, \text { this means we could not find sufficient } \\
\text { evidence to reject the hypothesis and conclude that the association between the two } \\
\text { attributes is insignificant at 5\% level. }\end{array}$ \\
\hline Conclusion & Thus there is insignificant association between preferred SNS and purpose of using SNS. \\
\hline
\end{tabular}

Objective 3:- To understand the relation in opinion on SNS affecting inter-personal relationship among colleagues and disturbing regular work in office.

\begin{tabular}{|l|l|l|l|l|l|}
\hline \multicolumn{2}{|c|}{} & \multicolumn{3}{l}{$\begin{array}{l}\text { Usage of mobile affects the inter-personal relationships } \\
\text { among colleagues }\end{array}$} \\
\cline { 3 - 6 } & $\begin{array}{l}\text { Strongly } \\
\text { agree }\end{array}$ & Agree & Disagree & $\begin{array}{l}\text { Strongly } \\
\text { disagree }\end{array}$ \\
\cline { 3 - 6 } & Count & Count & Count & Count \\
\hline \multirow{2}{*}{$\begin{array}{l}\text { usage of mobile in } \\
\text { meeting or office hours } \\
\begin{array}{l}\text { by your colleagues } \\
\text { disturbs the regular work }\end{array}\end{array}$} & Strongly agree & 2 & 2 & 4 & 0 \\
\cline { 2 - 6 } & Agree & 6 & 26 & 10 & 0 \\
\cline { 2 - 6 } & Neutral & 3 & 13 & 22 & 0 \\
\cline { 2 - 6 } & Disagree & 1 & 5 & 4 & 1 \\
\cline { 2 - 6 } & Strongly disagree & 1 & 0 & 0 \\
\hline
\end{tabular}

\section{Inference}

- There are 26 people who agree that inter-personal relations and regular work is affected by usage of SNS during office hours.

\begin{tabular}{|l|l|l|l|}
\hline Chi-Square Tests \\
\hline & Value & df & Asymp. Sig. (2-sided) \\
\hline Pearson Chi-Square & $26.860^{\mathrm{a}}$ & 12 & .008 \\
\hline Likelihood Ratio & 20.635 & 12 & .056 \\
\hline Linear-by-Linear Association & 1.920 & 1 & .166 \\
\hline N of Valid Cases & 100 & & \\
\hline a. 14 cells (70.0\%) have expected count less than 5. The minimum expected count is .01. \\
\hline
\end{tabular}

\section{Inference}

\begin{tabular}{|l|l|}
\hline Hypothesis & Ho: there is no significant association between the variables. \\
\hline Interpretation & $\begin{array}{l}\text { Since, the computed P-value }=0.008<0.05, \text { this means there is sufficient evidence to reject the } \\
\text { hypothesis and conclude that the association between the two attributes is significant at } 5 \% \text { level. }\end{array}$ \\
\hline Conclusion & Thus, there is significant association between inter-personal relations and regular work at office. \\
\hline
\end{tabular}

Objective 4:- To find out link in picking calls during work and allowing picking calls.

\begin{tabular}{|c|c|c|c|c|c|c|}
\hline \multicolumn{7}{|c|}{$\begin{array}{l}\text { allow colleagues to receive calls during the meeting * pick the phone during meeting Cross tabulatio } \\
\text { Count }\end{array}$} \\
\hline & & \multicolumn{4}{|c|}{ pick the phone during meeting } & \multirow[t]{2}{*}{ Total } \\
\hline & & Always & Sometimes & Rarely & Never & \\
\hline \multirow{5}{*}{$\begin{array}{l}\text { allow colleagues to receive } \\
\text { calls during the meeting }\end{array}$} & Always & 1 & 2 & 2 & 1 & 6 \\
\hline & Mostly & 0 & 2 & 6 & 2 & 10 \\
\hline & Sometimes & 0 & 19 & 15 & 10 & 44 \\
\hline & Rarely & 0 & 3 & 16 & 12 & 31 \\
\hline & Never & 0 & 1 & 1 & 7 & 9 \\
\hline \multicolumn{2}{|l|}{ Total } & 1 & 27 & 40 & 32 & 100 \\
\hline
\end{tabular}

\section{Inference}

- $\quad$ There are 19 people who sometimes pick calls and allow picking calls during work.
- There are 16 people who rarely pick calls and allow picking calls during work. 


\begin{tabular}{|c|c|c|c|}
\hline \multicolumn{4}{|l|}{ Chi-Square Tests } \\
\hline & Value & df & $\begin{array}{l}\text { Asymp. Sig. } \\
\text { (2-sided) }\end{array}$ \\
\hline Pearson Chi-Square & $37.268^{\mathrm{a}}$ & 12 & .000 \\
\hline Likelihood Ratio & 27.091 & 12 & .007 \\
\hline Linear-by-Linear Association & 12.591 & 1 & .000 \\
\hline $\mathrm{N}$ of Valid Cases & 100 & & \\
\hline \multicolumn{4}{|c|}{$\begin{array}{l}\text { a. } 14 \text { cells }(70.0 \%) \text { have expected count less than } 5 \text {. The minimum } \\
\text { expected count is } .06 \text {. }\end{array}$} \\
\hline
\end{tabular}

\section{Inference}

\begin{tabular}{|l|l|}
\hline Hypothesis & Ho: there is no significant association between the variables. \\
\hline Interpretation & $\begin{array}{l}\text { Since, the computed P-value }=0.000<0.05, \text { this means there is sufficient evidence to reject } \\
\text { the hypothesis and conclude that the association between the two attributes is significant at } \\
5 \% \text { level. }\end{array}$ \\
\hline Conclusion & Thus, there is significant association between pick calls and allow to pick calls during work. \\
\hline
\end{tabular}

Objective 5:- To understand relation in change in attitude and time spent on SNS.

\begin{tabular}{|c|c|c|c|c|c|c|}
\hline \multicolumn{7}{|c|}{$\begin{array}{l}\text { changes in your attitude because of using SNS * How often do you access social SNS per day Cross } \\
\text { tabulation } \\
\text { Count }\end{array}$} \\
\hline & & \multicolumn{4}{|c|}{ How often do you access social SNS per day } & \multirow[t]{2}{*}{ Total } \\
\hline & & $\begin{array}{l}\text { Less than half } \\
\text { an hour }\end{array}$ & $\begin{array}{l}\text { Half an hour } \\
\text { to an hour }\end{array}$ & 1-3hours & $\begin{array}{l}\text { More than } 3 \\
\text { hours }\end{array}$ & \\
\hline \multirow{2}{*}{$\begin{array}{l}\text { changes in your attitude } \\
\text { because of using SNS }\end{array}$} & Yes & 6 & 5 & 21 & 31 & 63 \\
\hline & No & 4 & 9 & 12 & 12 & 37 \\
\hline \multicolumn{2}{|l|}{ Total } & 10 & 14 & 33 & 43 & 100 \\
\hline
\end{tabular}

\section{Inference}

- Most of the people who feel a is a change in their attitude use SNS for Long hours i.e. 21 people use for 1-3 hours, 31 people use for more than 3 hours.

\begin{tabular}{|c|c|c|c|}
\hline \multicolumn{4}{|l|}{ Chi-Square Tests } \\
\hline & Value & df & Asymp. Sig. (2-sided) \\
\hline Pearson Chi-Square & $6.041^{\mathrm{a}}$ & 3 & .110 \\
\hline Likelihood Ratio & 5.902 & 3 & .116 \\
\hline Linear-by-Linear Association & 3.064 & 1 & .080 \\
\hline $\mathrm{N}$ of Valid Cases & 100 & & \\
\hline
\end{tabular}

\section{Inference}

\begin{tabular}{|l|l|}
\hline Hypothesis & Ho: there is no significant association between the variables. \\
\hline Interpretation & $\begin{array}{l}\text { Since, the computed P-value }=0.110>0.05, \text { this means we could not find sufficient evidence to } \\
\text { reject the hypothesis and conclude that the association between the two attributes is } \\
\text { insignificant at 5\% level. }\end{array}$ \\
\hline Conclusion & Thus there is insignificant association between Change in attitude and time spent on SNS. \\
\hline
\end{tabular}

Objective 6:- To find relation in monthly mobile bill and kind of connection.

\section{Descriptive}

\begin{tabular}{|ll|l|l|}
\hline \multicolumn{2}{|l|}{ Kind of mobile connection } & Mean & Std. error \\
\hline $\begin{array}{l}\text { Average monthly bill } \\
\text { (Rs.) (per month) }\end{array}$ & Pre-paid & 295.94 & 18.862 \\
\hline \multicolumn{2}{|c|}{ Post-paid } & 599.79 & 49.569 \\
\hline
\end{tabular}




\section{Inference}

- On an average, monthly bill of the respondents, who have Pre-paid connection (Rs. 296) is less than that of those who have Post-paid connection (Rs. $600)$.
- Average price of Post-paid connections of the respondents is double the average price of Pre-paid connections.

\begin{tabular}{|c|c|c|c|c|c|}
\hline \multicolumn{6}{|l|}{ Group Statistics } \\
\hline & kind of mobile connection & $\mathrm{N}$ & Mean & Std. Deviation & Std. Error Mean \\
\hline \multirow{2}{*}{$\begin{array}{l}\text { Q3. What is your average } \\
\text { monthly mobile bill? (Rs.) } \\
\text { (per month) }\end{array}$} & Pre-paid & 67 & 295.94 & 154.393 & 18.862 \\
\hline & Post-paid & 30 & 599.79 & 271.493 & 49.568 \\
\hline
\end{tabular}

\begin{tabular}{|c|c|c|c|c|c|c|c|c|c|c|}
\hline \multicolumn{11}{|c|}{ Independent Samples Test } \\
\hline & & \multicolumn{2}{|c|}{\begin{tabular}{|l|} 
Levene's \\
Test for \\
Equality of \\
Variances \\
\end{tabular}} & \multicolumn{7}{|c|}{ t-test for Equality of Means } \\
\hline & & \multirow[t]{2}{*}{$\mathbf{F}$} & \multirow[t]{2}{*}{ Sig. } & \multirow[t]{2}{*}{$\mathbf{t}$} & \multirow[t]{2}{*}{ df } & \multirow[t]{2}{*}{$\begin{array}{l}\text { Sig. } \\
(2- \\
\text { tailed })\end{array}$} & \multirow[t]{2}{*}{$\begin{array}{l}\text { Mean } \\
\text { Difference }\end{array}$} & \multirow[t]{2}{*}{$\begin{array}{l}\text { Std. Error } \\
\text { Difference }\end{array}$} & \multicolumn{2}{|c|}{$\begin{array}{l}95 \% \text { Confidence } \\
\text { Interval of the } \\
\text { Difference }\end{array}$} \\
\hline & & & & & & & & & Lower & Upper \\
\hline \multirow{2}{*}{$\begin{array}{l}\text { Q3. What is } \\
\text { your } \\
\text { average } \\
\text { monthly } \\
\text { mobile bill? } \\
\text { (Rs.) (per } \\
\text { month) }\end{array}$} & $\begin{array}{l}\text { Equal } \\
\text { variances } \\
\text { assumed } \\
\end{array}$ & 5.861 & .017 & $\begin{array}{l}- \\
6.999\end{array}$ & 95 & .000 & -303.854 & 43.417 & -390.047 & -217.660 \\
\hline & $\begin{array}{l}\text { Equal } \\
\text { variances } \\
\text { not } \\
\text { assumed }\end{array}$ & & & $\begin{array}{l}- \\
5.729\end{array}$ & 37.660 & .000 & -303.854 & 53.035 & -411.250 & -196.458 \\
\hline
\end{tabular}

\section{Inference}

\begin{tabular}{|l|l|}
\hline Hypothesis & Ho: there is no significant association between the variables \\
\hline Interpretation & $\begin{array}{l}\text { Since, the computed P-value }=0.000<0.05, \text { this means there is sufficient evidence to } \\
\text { reject the hypothesis and conclude that the association between the two attributes is } \\
\text { significant at } 5 \% \text { level. }\end{array}$ \\
\hline Conclusion & $\begin{array}{l}\text { Thus, there is significant association between monthly mobile bill and kind of } \\
\text { connection. }\end{array}$ \\
\hline
\end{tabular}

\section{CONCLUSION}

This study deals with understanding of people's opinion on SNS and how it affects their work efficiency and their interpersonal relations.

SNS is an inseparable part of people's life in today's world. It has become more of a necessity rather than a luxury, but it has its pitfalls too. Excessive use of it can disrupt their schedule causing severe troubles in one's inter-personal relationships and work effectiveness, as we could somewhat find, through the study, that some people noticed a change in their attitude because of excessive usage of SNSs.

In organisations, SNSs can play an empirical role in improving the way activities, functions and processes are carried on. Also the way in which interactions with suppliers, investors, customers, government, employees etc are done. Thus improving output and profitability of organisations drastically who allow tech friendly ways into their work?
SNS have positive and negative effects based on its kind and extent of use. Thus it becomes necessary for one to understand the repercussions and adapt it in a way it is optimally used to make life easier and happier.

\section{ACKNOWLEDGEMENT}

The completion of this study is the result of help of a lot of people. I am extremely thankful to the respondents who participated in the study and enabled me in getting the required data. I also extend my sincere gratitude to Dr. Prabhat Mittal, Associate Professor, Satyawati College, University of Delhi, for his support and guidance that was required for this study.

\section{SUGGESTIONS}

- SNSs impacting people's decisions in their personal lives.

- Measure of peer pressure on teenagers because on usage of SNS.

- People's perception about reliance on information available SNSs. 


\section{REFERENCES}

1. Katz E, Blumler JG, Gurevitch M. Uses and gratifications research. The public opinion quarterly. 1973 Dec 1;37(4):509-23.

2. Rubin KH, Coplan RJ, Bowker JC. Social withdrawal in childhood. Annual review of psychology. 2009 Jan 10;60:141-71.

3. AlAjmi A, Abou-Ziyan H, Ghoneim A. Achieving annual and monthly net-zero energy of existing building in hot climate. Applied Energy. 2016 Mar 1;165:511-21.

4. Chakraborty P, Mittal P, Gupta MS, Yadav S, Arora A. Opinion of students on online education during the COVID- 19 pandemic. Human Behavior and Emerging Technologies.

5. James S. Is Technology Networking Changing Childhood. A National Poll by Common Sense Media, San Francisco. 2009.
6. Ahmed I, Qazi TF. A look out for academic impacts of Social networking sites (SNSs): A student based perspective. African Journal of Business Management. 2011 Jun 30;5(12):5022-31.

7. Coyle CL, Vaughn H. Social networking: Communication revolution or evolution?. Bell Labs technical journal. 2008;13(2):13-7.

8. Valenzuela S, Park N, Kee KF. Is there social capital in a social network site?: Facebook use and college students' life satisfaction, trust, and participation. Journal of computer-mediated communication. 2009 Jul 1;14(4):875-901.

9. Brandtzæg PB, Heim J, Karahasanović A. Understanding the new digital divide - A typology of Internet users in Europe. International journal of human-computer studies. 2011 Mar 1;69(3):12338. 